\title{
Analisis Nilai Pasar Tanah Perumahan Kawasan Industri Tuban (KIT) dengan Metode Pengembangan Lahan
}

\author{
Devi Santi Maharani dan Retno Indryani \\ Jurusan Teknik Sipil, Fakultas Teknik Sipil dan Perencanaan, Institut Teknologi Sepuluh Nopember (ITS) \\ Jl. Arief Rahman Hakim, Surabaya 60111 Indonesia \\ e-mail:smaharanidevi@gmail.com
}

\begin{abstract}
Abstrak - Lahan perumahan Kawasan Industri Tuban cukup luas. Untuk melakukan estimasi nilai pasar lahan tersebut tidak mungkin menggunakan Metode Perbandingan Data Pasar, karena tidak ada data pembanding yang bisa digunakan. Metode yang lebih tepat adalah Metode Pengembangan Tanah atau Land Development Approach, yaitu metode penilaian tanah dengan cara mengasumsikan bagaimana tanah tersebut akan dikembangkan. Penelitian ini bertujuan untuk menganalisis nilai pada tanah Perumahan Kawasan Industri Tuban dengan metode Pengembangan Tanah.

Dasar analisis dari Metode Pengembangan Tanah adalah rencana pengembangan, yang didasarkan pada Highest and Best Use tanah tersebut. Berdasarkan rencana pengembangan lahan, akan dihitung nilai pasar tanah dengan metode arus kas. Nilai pasar tanah diperoleh dengan cara mengurangi pendapatan kotor tanah dan properti dengan biaya pengembangan dan biaya-biaya yang berhubungan dengan pengembangan tanah. Dari hasil analisis diketahui indikasi nilai pasar tanah di Kawasan Industri Tuban yang akan dibangun menjadi perumahan sebesar Rp.299.917 per $\mathbf{m}^{2}$
\end{abstract}

Kata Kunci-Metode Arus Kas, Metode Pengembangan Lahan, Nilai Pasar Tanah

\section{PENDAHULUAN}

$\mathrm{S}_{\mathrm{p}}^{\mathrm{E}}$ EIRING dengan perkembangan jaman, pertumbuhan penduduk beserta aktifitas kota dan kabupaten juga semakin meningkat. Hal tersebut juga mengakibatkan meningkatnya permintaan lahan sebagai wadah untuk menampung aktivitas masyarakat yang ada. Lahan memiliki peranan penting dalam pengelolaan kabupaten atau kota. Oleh karena itu perlu dioptimalisasikan dan diketahui nilai pasarnya agar dapat digunakan lebih lanjut dalam menentukan harga jual atau sewa, sesuai properti yang akan dibangun. Nilai pasar merupakan prakiraan jumlah uang pada tanggal penilaian suatu aset yang digunakan untuk transaksi jual beli atau penukaran suatu properti. Selain untuk menentukan harga jual atau sewa, nilai pasar pada lahan dapat digunakan pengembang untuk mengetahui besarnya aset yang dimiliki, dan juga dapat dimanfaatkan menjadi nilai likuidasi maupun agunan.

Di sisi timur Kawasan Industri Tuban terdapat lahan kosong yang memiliki potensi dikembangkan menjadi suatu kawasan hunian, Nilai pasar lahan perlu ditentukan sehingga dapat bermanfaat bagi pengembang.

Lahan yang tersedia untuk perumahan ini cukup luas dan sulit dicari data pembandingnya karena tidak ada luasan tanah yang serupa dengan karakter-karakter tanah yang akan dinilai. Oleh karena itu metode Perbandingan Data Pasar tidak dapat digunakan. Metode yang lebih tepat digunakan untuk penilaian ini adalah metode Pengembangan Lahan atau Land Development Approach, dimana penentuan nilai pasar tanah dilakukan dengan cara membuat asumsi rencana bagaimana lahan tersebut akan dikembangkan, seperti rencana penjualan, discount rate, dan biaya pengembangannya [1].

Tujuan dari penelitian ini adalah melakukan analisis indikasi nilai pasar tanah di Kawasan Industri Tuban yang akan dibangun perumahan berdasarkan metode Pengembangan Lahan. Dari hasil analisis dapat diketahui indikasi nilai pasar tanah per $\mathrm{m}^{2}$.

\section{TINJAUAN PUSTAKA}

\section{A. Metode Pengembangan Lahan (Land Development}

Approach)

Metode pengembangan lahan merupakan metode penilaian dengan cara mengasumsikan bagaimana tanah tersebut akan dikembangkan. Terdapat beberapa kriteria suatu tanah dapat dinilai dengan metode ini:

1) Digunakan bila tanah terletak di daerah berkembang.

2) Data harga pasar sulit diperoleh

3) Data harga jual dari tanah yang dikembangkan dapat diperoleh

4) Memiliki potensi untuk dikembangkan sebagai daerah pemukiman, pertokoan atau perindustrian.

5) Tanah harus terletak pada daerah yang relatif ideal dan memiliki aksesibilitas yang baik.

Gambar 1 menunjukkan ilustrasi dari metode Land Development [2]. Gross Development Value atau GDV merupakan nilai estimasi yang didapat dari program penjualan. Development Cost atau DC merupakan nilai yang didapat dari biaya pengembangan. Development Profit atau DP merupakan keuntungan pengembang. Residual Value merupakan hasil pengurangan GDV, DC dan DP. Discounting factor merupakan bilangan yang dipakai untuk mengalikan suatu jumlah nilai dimasa yang akan datang untuk menjadi nilai sekarang.

Dihitung menggunakan rumus (1), dimana i merupakan discount rate / tingkat bunga dan $\mathrm{n}$ merupakan tahun ke-n.

$$
\text { Discount Factor }=\frac{1}{(1+i)^{n}}
$$




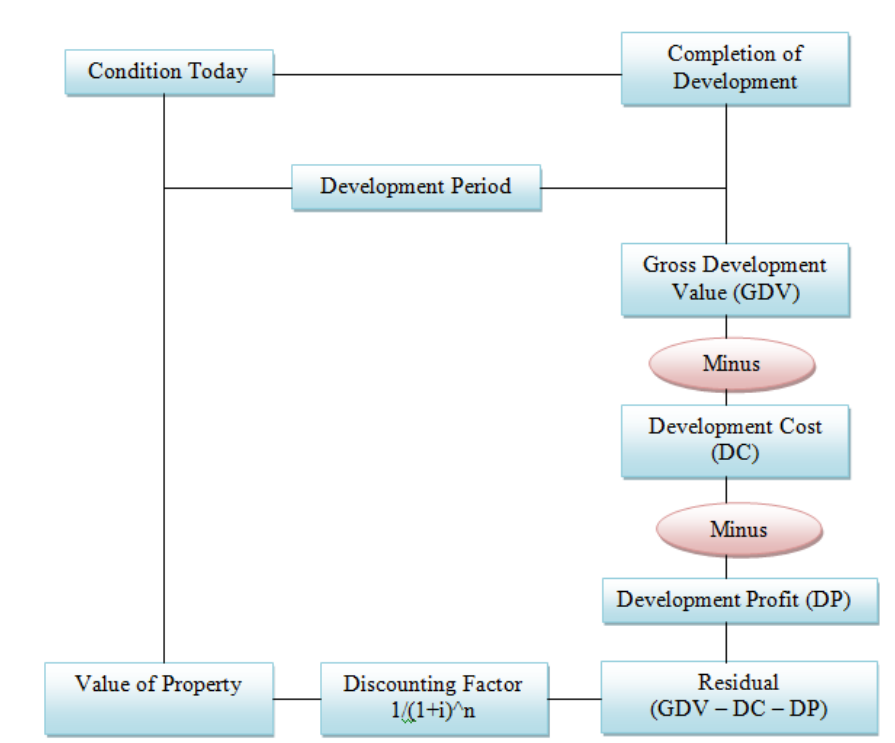

Gambar 1. Ilustrasi Land Development Analysis

\section{METODOLOGI}

Diagram alir penelitian dapat dilihat pada gambar 2. Pada metode Land Development, rencana pendapatan diperoleh dari rencana pengembangan yang terdiri dari rencana pembangunan dan penjualan. Biaya pengembangan diperoleh dari penjumlahan biaya konstruksi rumah dan fasilitas pendukung, biaya pemasaran, serta biaya overhead. Sedangkan keuntungan pengembang diperoleh dari wawancara dengan pengembang atau pemilik properti sejenis.

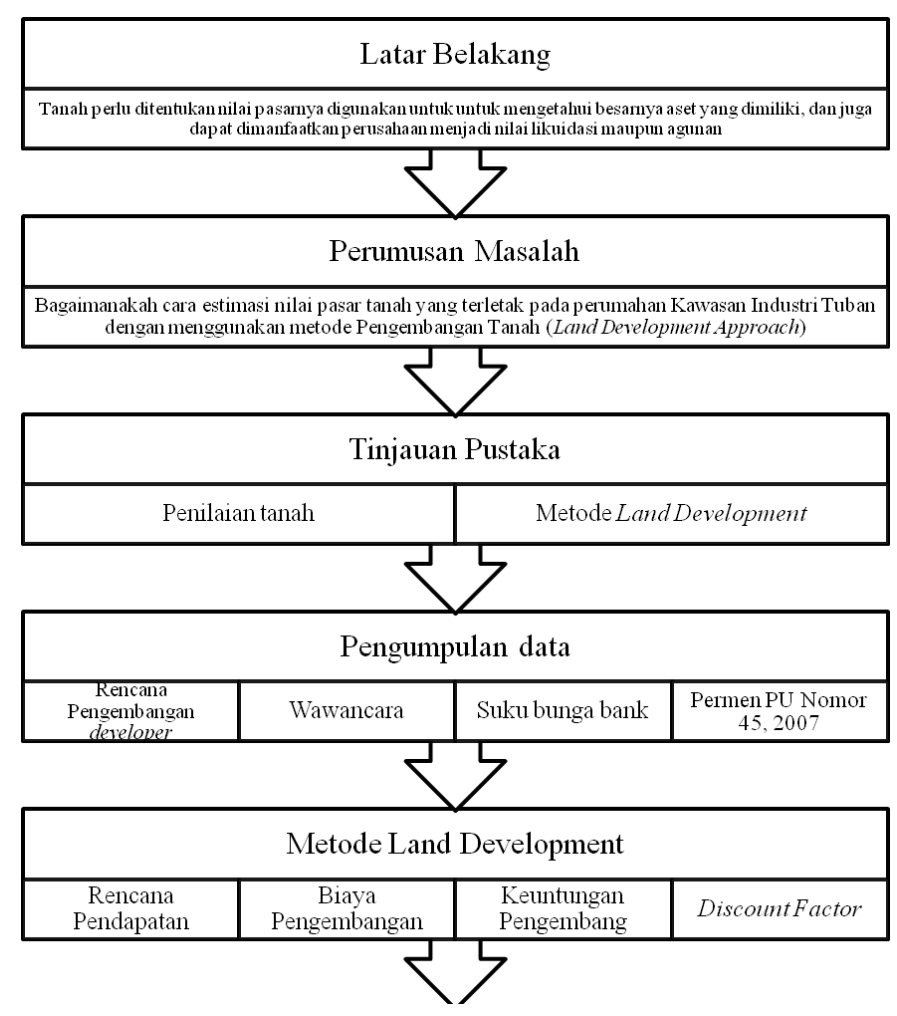

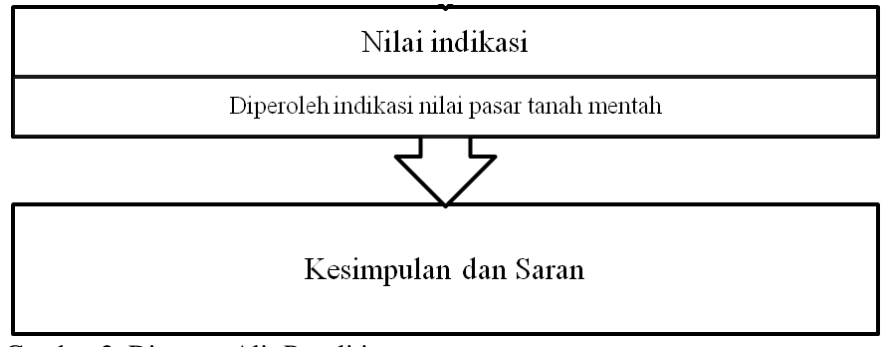

Gambar 2. Diagram Alir Penelitian

\section{ANALISIS DAN PEMBAHASAN}

\section{A. Gambaran Umum Objek Penelitian}

Lokasi lahan berada pada Desa Temaji, Kecamatan Jenu, Kabupaten Tuban. Jaraknya pada pusat kota mencapai $\pm 21 \mathrm{~km}$, dan posisinya berada pada sisi Utara dalam Kabupaten Tuban, berupa dataran rendah dengan elevasi berkisar antara $2-6$ meter diatas permukaan laut. Kondisi lingkungan sekitar masih berupa lahan pertanian dan perkebunan, kondisi perumahan sendiri masih berupa rumah sangat sederhana yang telah tumbuh padat penduduk. KIT mencakup lahan seluas \pm 233.5 Ha. Lahan KIT termasuk pada area dengan peruntukan sebagai zona industri yang memiliki status hukum Hak Milik bersertifikat [3].

\section{B. Analisis Pasar Perumahan}

Kondisi perumahan yang ada di Kecamatan Jenu sebagian besar merupakan rumah sangat sederhana yang berada di pedesaan dan dibangun berdasarkan kebutuhan sendiri. Sedangkan perumahan yang dibangun oleh pengembang kondisinya belum merata dan sebagian besar lebih terpusat di Kota Tuban. Mengingat adanya perkembangan industri di Kecamatan Jenu, sudah ada beberapa perubahan yang dibuat oleh dinas PU setempat untuk mengembangkan kawasan perumahan, termasuk komplek Kawasan Industri Tuban.

Terdapat data perumahan lain di Tuban yang digunakan selain data KIT sebagai pembanding. Properti pembanding diperlukan untuk mencari harga jual rumah pada subyek yang ditinjau. Terdapat Perumahan Tuban Indah sebagai pembanding rumah tipe 80, Perumahan Megatama Regency Tuban sebagai pembanding rumah tipe 52, Perumahan Florencia Regency sebagai pembanding rumah tipe 42, 60, dan 80, Perumahan Grand Executive sebagai pembanding rumah tipe 60 dan 80, Perumahan Marina Residence sebagai pembanding rumah tipe 42 dan 52, Perumahan Perbon Raya 2 sebagai pembanding rumah tipe $42,52,60$, dan 80 . Pertimbangan dalam mengambil beberapa perumahan sebagai pembanding didasarkan pada beberapa kriteria seperti lokasi, lingkungan sekitar, tipe rumah, serta jarak dari lahan KIT.

\section{Analisis Pengembangan Lahan Perumahan}

Kawasan Industri Tuban (KIT) terbagi menjadi kawasan industri, kawasan hunian, dan kawasan komersial. Lokasi KIT ini cukup strategis, karena langsung berbatasan dengan jalan raya Surabaya-Semarang pada sisi utara.

Konsep penataan rumah pada perumahan didasarkan pada jenis atau tipe rumah yang dibangun. Rumah tipe 80 adalah rumah dengan ukuran bangunan paling besar di antara tipe lainnya. Sebagian dari rumah tipe ini diletakkan di sepanjang 
jalan utama perumahan. Sebagian lainnya diletakkan di dalam cluster. Begitu juga dengan rumah tipe 60 , sebagian diletakkan di jalan utama dan sebagian lagi di kelompokkan dalam sebuah cluster. Tipe 52 seluruhnya dikelompokkan dalam sebuah cluster. Sedangkan rumah tipe 42 sebagian kecil diletakkan di luar cluster dan mayoritas ada di dalam cluster dan berada di posisi paling jauh dari jalan utama di dalam perumahan. Perkerasan memakai paving stone. Jarak ke pusat kota mencapai $\pm 19 \mathrm{~km}$. Data rumah per tipe ada pada Tabel 1 .

Tabel 1.

Data Rumah Perumahan KIT

\begin{tabular}{|c|c|c|c|}
\hline Tipe & $\begin{array}{c}\text { Luas tanah } \\
\left(\mathbf{m}^{2}\right)\end{array}$ & $\begin{array}{c}\text { Luas Bangunan } \\
\left(\mathrm{m}^{2}\right)\end{array}$ & $\begin{array}{c}\text { Banyaknya } \\
\text { Unit }\end{array}$ \\
\hline 80 & 250 & 80 & 112 \\
\hline 60 & 220 & 60 & 82 \\
\hline 52 & 180 & 52 & 207 \\
\hline 42 & 114 & 42 & 76 \\
\hline \multicolumn{3}{|r|}{ Total } & 477 \\
\hline
\end{tabular}

Fasilitas Penunjang yang ada di perumahan berupa gerbang perumahan, ruang terbuka hijau dan fasilitas olahraga, dua bangunan Masjid, asrama, gedung TK, gedung SD, serta jalan \& saluran. Untuk menghitung pendapatan dan biaya pengembangan diperlukan jadwal pembangunan serta rencana penjualan perumahan KIT. Rencana pembangunan dapat dilihat pada Tabel 2, Rencana penjualan dapat dilihat pada Tabel 3.

Tabel 2.

Rencana Pembangunan Perumahan KIT

\begin{tabular}{|l|c|c|c|c|c|c|c|c|c|c|}
\hline \multicolumn{1}{|c|}{ Uraian } & $\mathbf{2 0 1 6}$ & $\mathbf{2 0 1 7}$ & $\mathbf{2 0 1 8}$ & $\mathbf{2 0 1 9}$ & $\mathbf{2 0 2 0}$ & $\mathbf{2 0 2 1}$ & $\mathbf{2 0 2 2}$ & $\mathbf{2 0 2 3}$ & $\mathbf{2 0 2 4}$ \\
\hline $\begin{array}{l}\text { Rencana Pembangunan } \\
\text { Per Tahun }\end{array}$ & \multicolumn{2}{|c|}{143} & \multicolumn{5}{|c|}{191} & \multicolumn{2}{c|}{95} & \multicolumn{2}{c|}{48} \\
\hline Tipe 80/250 & 56 & 56 & & & & & & & \\
\hline Tipe 60/220 & & 31 & 51 & & & & & & \\
\hline Tipe 52/180 & & & 13 & 64 & 63 & 48 & 19 & & \\
\hline Tipe 42/114 & & & & & & & 28 & 24 & 24 \\
\hline Jalan \& Saluran & 1 & & & & & & & & \\
\hline Masjid & 1 & 1 & & & & & & & \\
\hline Asrama & 1 & & & & & & & & \\
\hline Gedung TK & 1 & 1 & & & & & & & \\
\hline Gedung SD & 1 & & & & & & & & \\
\hline
\end{tabular}

Sumber: Hasil Perhitungan dan Analisis

Pembangunan fasilitas pendukung seperti Masjid, Asrama, gedung TK, dan gedung SD serta jalan dan saluran direncanakan akan selesai sebelum pemasaran rumah dimulai, yaitu tahun 2016. Sisanya dibangun saat tahun pertama pemasaran, yaitu tahun 2017.

Tabel 3.

Rencana Penjualan Perumahan KIT Berdasarkan Tipe Rumah

\begin{tabular}{|c|c|c|c|c|c|c|c|c|c|c|}
\hline \multicolumn{2}{|c|}{ Uraian } & 2016 & 2017 & 2018 & 2019 & 2020 & 2021 & 2022 & 2023 & 2024 \\
\hline \multicolumn{3}{|c|}{$\begin{array}{l}\text { Rencana Penjualan Per } \\
\text { Tahun }\end{array}$} & 70 & 80 & 90 & 90 & 50 & 40 & 30 & 27 \\
\hline \multirow{4}{*}{$\begin{array}{l}\text { Rencana } \\
\text { Penjualan } \\
\text { (unit) }\end{array}$} & \begin{tabular}{|l|} 
Tipe 80/250 \\
\end{tabular} & & 70 & 42 & & & & & & \\
\hline & \begin{tabular}{|l} 
Tipe $60 / 220$ \\
\end{tabular} & & & 38 & 44 & & & & & \\
\hline & \begin{tabular}{|l|} 
Tipe $52 / 180$ \\
\end{tabular} & & & & 46 & 90 & 50 & 21 & & \\
\hline & Tipe 42/114 & & & & & & & 19 & 30 & 27 \\
\hline
\end{tabular}

Sumber: Hasil Perhitungan dan Analisis

\section{Analisis Pendapatan}

Pendapatan diperoleh dari hasil penjualan rumah. Penentuan harga jual rumah didapat dari perbandingan harga pasar antara properti yang dinilai dengan properti pembanding. Perhitungan dilakukan berdasarkan tipe rumah yang ada. Metode yang dipakai adalah metode presentase yaitu jika properti yang dinilai mempunyai faktor lebih dari pembanding maka penyesuaiannya positif $(+\%)$, sedangkan jika properti yang dinilai mempunyai faktor kurang dari pembanding, maka penyesuaiannya negatif (-\%) [4]. Contoh perhitungan perbandingan data pasar dapat dilihat pada Tabel 4. Tabel 5 menunjukkan harga jual masing-masing tipe rumah dari hasil perhitungan perbandingan data pasar.

Tabel 4.

Perhitungan Perbandingan Data Pasar Rumah Tipe 42 (dalam Ribu Rupiah)

\begin{tabular}{|c|c|c|c|c|}
\hline \multirow{2}{*}{ Data Properti } & \multirow{2}{*}{$\begin{array}{c}\text { Properti yang } \\
\text { Dinilai } \\
\begin{array}{c}\text { Perumahan } \\
\text { KIT }\end{array} \\
\end{array}$} & \multicolumn{3}{|c|}{ Properti Pembanding } \\
\hline & & $\begin{array}{c}\text { Florencia } \\
\text { Regency }\end{array}$ & $\begin{array}{c}\text { Marina } \\
\text { Residence }\end{array}$ & $\begin{array}{c}\text { Perbon Raya } \\
2\end{array}$ \\
\hline Tahun transaksi & 2016 & 2016 & 2016 & 2015 \\
\hline Luas bangunan $\left(\mathrm{m}^{2}\right)$ & 42 & 45 & 42 & 45 \\
\hline Luas $\tan a \mathrm{~h}\left(\mathrm{~m}^{2}\right)$ & 144 & 77 & 109 & 75 \\
\hline Lokasi & $\begin{array}{l}\text { Di belakang } \\
\text { perumahan }\end{array}$ & $\begin{array}{l}\text { Di belakang } \\
\text { perumahan }\end{array}$ & $\begin{array}{l}\text { Di belakang } \\
\text { perumahan }\end{array}$ & $\begin{array}{l}\text { Di belakang } \\
\text { perumahan }\end{array}$ \\
\hline Lebar jalan (m) & 7 & 8 & 8 & 8 \\
\hline Fasilitas Penunjang & $\begin{array}{c}\text { Listrik, air } \\
\text { bersih }\end{array}$ & $\begin{array}{c}\text { Listrik, air } \\
\text { bersih }\end{array}$ & $\begin{array}{c}\text { Listrik, air } \\
\text { bersih }\end{array}$ & $\begin{array}{c}\text { Listrik, air } \\
\text { bersih }\end{array}$ \\
\hline Perkerasan jalan & Paving Stone & Paving Stone & Paving Stone & Paving Stone \\
\hline Kualitas bangunan & Standar & Standar & Standar & Standar \\
\hline Harga Jual & & 350.000 & 367.960 & 288.012 \\
\hline \multicolumn{5}{|c|}{ PENYESUAIAN (dalam \%) } \\
\hline Tahun transaksi & & 0 & 0 & 6,5 \\
\hline Luas bangunan $\left(\mathrm{m}^{2}\right)$ & & $-7,143$ & 0 & $-7,143$ \\
\hline Luas tanah $\left(\mathrm{m}^{2}\right)$ & & 46,528 & 24,306 & 47,917 \\
\hline Lokasi & & 0 & 0 & 0 \\
\hline Lebar jalan $(\mathrm{m})$ & & $-1,484$ & $-1,048$ & $-1,524$ \\
\hline Fasilitas Penunjang & & 0 & 0 & 0 \\
\hline Perkerasan jalan & & 0 & 0 & 0 \\
\hline Kualitas bangunan & & 0 & 0 & 0 \\
\hline Total Penyesuaian & & 137,901 & 123,257 & 145,750 \\
\hline Nilai Indikasi & & 482.652 & 453.537 & 419.777 \\
\hline
\end{tabular}

Sumber: Hasil Perhitungan dan Analisis

Tabel 5.

Harga Jual Per Tipe Rumah (dalam Ribu Rupiah)

\begin{tabular}{|c|c|}
\hline Tipe Rumah & Harga Jual \\
\hline Tipe $80 / 250$ & 872.898 \\
\hline Tipe 60/220 & 680.104 \\
\hline Tipe 52/180 & 509.123 \\
\hline Tipe 42/114 & 452.143 \\
\hline
\end{tabular}

Estimasi Pendapatan dari perumahan KIT didapat dari harga jual rumah yang mengalami kenaikan harga setiap tahunnya. Besarnya penyesuaian untuk kenaikan harga jual rumah diperkirakan sebesar $10 \%$ per tahun. Perhitungan kenaikan harga jual rumah terdapat pada Tabel 6. Pendapatan per tahun perumahan KIT diperoleh dari perkalian harga jual tipe rumah per tahun dengan rencana penjualan unit tipe rumah per tahun. Pendapatan per tahun dari pembangunan perumahan KIT terdapat pada Tabel 7. 
Tabel 6.

Perhitungan Kenaikan Harga Jual Rumah Per Tahun (dalam Ribu Rupiah)

\begin{tabular}{|l|c|c|c|c|}
\hline & Tipe 80/250 & Tipe 60/220 & Tipe 52/180 & Tipe 42/114 \\
\hline $\mathbf{2 0 1 6}$ & 872.898 & 680.104 & 509.123 & 452.143 \\
\hline $\mathbf{2 0 1 7}$ & 960.188 & 748.115 & 560.035 & 497.358 \\
\hline $\mathbf{2 0 1 8}$ & 1.056 .207 & 822.926 & 616.039 & 547.094 \\
\hline $\mathbf{2 0 1 9}$ & 1.161 .828 & 905.219 & 677.643 & 601.803 \\
\hline $\mathbf{2 0 2 0}$ & 1.278 .010 & 995.741 & 745.407 & 661.983 \\
\hline $\mathbf{2 0 2 1}$ & 1.405 .811 & 1.095 .315 & 819.948 & 728.182 \\
\hline $\mathbf{2 0 2 2}$ & 1.546 .393 & 1.204 .846 & 901.943 & 801.000 \\
\hline $\mathbf{2 0 2 3}$ & 1.701 .032 & 1.325 .331 & 992.137 & 881.100 \\
\hline $\mathbf{2 0 2 4}$ & 1.871 .135 & 1.457 .864 & 1.091 .351 & 969.210 \\
\hline
\end{tabular}

Sumber: Hasil Perhitungan dan Analisis

Tabel 7.

Pendapatan Per Tahun Perumahan KIT (dalam Ribu Rupiah)

\begin{tabular}{|c|c|c|c|c|c|c|c|c|c|}
\hline Uraian & 2016 & 2017 & 2018 & 2019 & 2020 & 2021 & 2022 & 2023 & 2024 \\
\hline Tipe 80/250 & & 67.213 .168 & 44.360 .691 & & & & & & \\
\hline Tipe 60/220 & & & 31.271 .190 & 39.829 .621 & & & & & \\
\hline Tipe 52/180 & & & & 31.171 .573 & 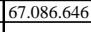 & 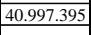 & 18.940 .796 & & \\
\hline Tipe 42/114 & & & & & & & 15.218 .994 & 26.432 .989 & 26.168 .659 \\
\hline $\begin{array}{l}\text { Total } \\
\text { Pendapatan }\end{array}$ & - & 67.213 .168 & 75.631.881 & 71.001.194 & 67.086 .646 & 40.997 .395 & 34.159 .790 & 26.432 .989 & 26.168 .659 \\
\hline
\end{tabular}

\section{E. Analisis Biaya Pengembangan}

Biaya Pengembangan terdiri dari biaya konstruksi, biaya cut \& fill, biaya perizinan, biaya pemasaran, dan biaya overhead. Biaya konstruksi terdiri dari biaya pembangunan rumah, pembuatan jalan dan saluran, serta fasilitas penunjang lainnya seperti masjid, asrama, gedung TK \& SD, dan balai warga. Biaya konstruksi rumah, jalan, dan saluran didapat dari RAB pengembang sedangkan fasilitas penunjang didapat dari harga per $\mathrm{m} 2$ bangunan yang dihitung berdasarkan Permen PU No: 45/PRT/M/2007 [5]. Besarnya penyesuaian untuk kenaikan biaya konstruksi rumah diperkirakan sebesar $10 \%$ per tahun. Perhitungan kenaikan biaya konstruksi terdapat pada Tabel 8.

Tabel 8.

Perhitungan Kenaikan Biaya Konstruksi Rumah Per Tahun (dalam Ribu Rupiah)

\begin{tabular}{|c|c|c|c|c|}
\hline & Tipe 80/250 & Tipe 60/220 & Tipe 52/180 & Tipe 42/114 \\
\hline $\mathbf{2 0 1 6}$ & 299.872 & 238.008 & 212.618 & 193.496 \\
\hline $\mathbf{2 0 1 7}$ & 329.859 & 261.809 & 233.880 & 212.846 \\
\hline $\mathbf{2 0 1 8}$ & 362.845 & 287.990 & 257.268 & 234.130 \\
\hline $\mathbf{2 0 1 9}$ & 399.130 & 316.789 & 282.995 & 257.543 \\
\hline $\mathbf{2 0 2 0}$ & 439.043 & 348.468 & 311.294 & 283.297 \\
\hline $\mathbf{2 0 2 1}$ & 482.947 & 383.314 & 342.423 & 311.627 \\
\hline $\mathbf{2 0 2 2}$ & 531.242 & 421.646 & 376.666 & 342.790 \\
\hline $\mathbf{2 0 2 3}$ & 584.366 & 463.810 & 414.332 & 377.069 \\
\hline $\mathbf{2 0 2 4}$ & 642.802 & 510.191 & 455.766 & 414.776 \\
\hline
\end{tabular}

Total biaya konstruksi rumah per tahunnya diperoleh dari hasil perkalian biaya konstruksi rumah per tahun dengan rencana pembangunan unit rumah per tahun. Perhitungan total biaya konsttruksi rumah terdapat pada Tabel 9. Biaya konstruksi jalan dan saluran didapat dari RAB pengembang sebesar Rp. 20,796,573,200. Direncanakan jalan dan saluran akan selesai dalam jangka waktu satu tahun, yaitu tahun 2016.

Perhitungan biaya fasilitas penunjang lainnya didapat dari perhitungan biaya konstruksi fisik yang terdiri dari biaya Standar dan biaya Non-Standar [6]. Biaya Standar diperoleh dari harga satuan tertinggi rata-rata per- $\mathrm{m}^{2}$ bangunan gedung bertingkat dikalikan dengan luas rancang dan koefisien/faktor pengali untuk jumlah lantai yang bersangkutan.
Tabel 9.

Total Biaya Konstruksi Rumah Per Tahun (dalam Ribu Rupiah)

\begin{tabular}{|c|c|c|c|c|}
\hline Uraian & Tipe 80/250 & Tipe 60/220 & Tipe 52/180 & Tipe 42/114 \\
\hline $\begin{array}{c}\text { Banyaknya } \\
\text { Unit }\end{array}$ & 112 & 82 & 207 & 76 \\
\hline $\mathbf{2 0 1 6}$ & 16.792 .832 & & & \\
\hline $\mathbf{2 0 1 7}$ & 18.472 .115 & 8.116 .073 & & \\
\hline $\mathbf{2 0 1 8}$ & & 14.687 .474 & 3.344 .481 & \\
\hline $\mathbf{2 0 1 9}$ & & & 18.111 .652 & \\
\hline $\mathbf{2 0 2 0}$ & & & 19.611 .523 & \\
\hline $\mathbf{2 0 2 1}$ & & & 16.436 .324 & \\
\hline $\mathbf{2 0 2 2}$ & & & 7.156 .649 & 9.598 .119 \\
\hline $\mathbf{2 0 2 3}$ & & & & 9.049 .655 \\
\hline $\mathbf{2 0 2 4}$ & & & & 9.954 .621 \\
\hline
\end{tabular}

Biaya non-standar diperoleh dari perkalian prosentase jenis pekerjaan yang dipilih dengan total biaya pekerjaan standar. Syarat total biaya pekerjaan non-standar maksimum $150 \%$ dari total biaya pekerjaan standar bangunan gedung yang bersangkutan. Harga satuan tertinggi rata-rata per- $\mathrm{m}^{2}$ bangunan tidak sederhana sebesar Rp. 6.834.000, sedangkan bangunan sederhana sebesar Rp. 5.257.000. Tabel 10 perhitungan biaya fasilitas penunjang berdasarkan. Besarnya penyesuaian untuk kenaikan biaya konstruksi fasilitas penunjang diperkirakan sebesar $10 \%$ per tahun. Perhitungan kenaikan biaya konstruksi fasilitas penunjang terdapat pada Tabel 11. Biaya cut \& fill perumahan KIT dapat dilihat pada Tabel 12.

Tabel 10.

Total Biaya Konstruksi Fisik Fasilitas Penunjang (dalam Ribu Rupiah)

\begin{tabular}{|l|c|c|c|c|}
\hline & Masjid & Asrama/Dorm & Gedung TK & Gedung SD \\
\hline Biaya Standar & 732.410 & 11.242 .802 & 2.406 .655 & 11.460 .260 \\
\hline Biaya Non-Standar & 219.723 & 3.372 .840 & 721.996 & 3.438 .078 \\
\hline Total & 952.132 & 14.615 .642 & 3.128 .651 & 14.898 .338 \\
\hline
\end{tabular}

Tabel 11.

Perhitungan Kenaikan Biaya Konstruksi Fasilitas Penunjang Per Tahun (dalam Ribu Rupiah)

\begin{tabular}{|l|c|c|c|c|}
\hline & Masjid & Asrama/Dorm & Gedung TK & Gedung SD \\
\hline Biaya Standar & 732.410 & 11.242 .802 & 2.406 .655 & 11.460 .260 \\
\hline Biaya Non-Standar & 219.723 & 3.372 .840 & 721.996 & 3.438 .078 \\
\hline Total & 952.132 & 14.615 .642 & 3.128 .651 & 14.898 .338 \\
\hline
\end{tabular}

Tabel 12.

Biaya Cut \& Fill

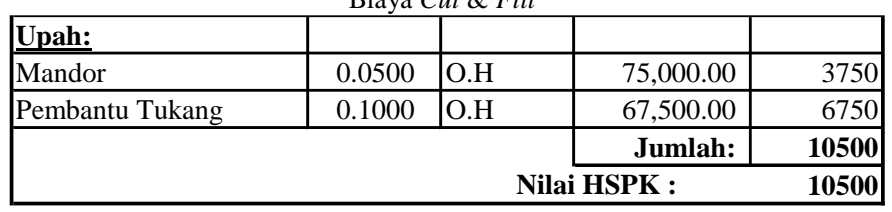

Biaya perizinan terdiri dari biaya IMB (Perda Kabupaten Tuban no 06 tahun 2011) dan SPPT. Perhitungan biaya perizinan diperkirakan sebesar 5\% dari total biaya konstruksi. Sehingga biaya perizinan didapat sebesar $5 \%$ x Rp. 210.211.715.805 = Rp. 10.510.585.790. Biaya pemasaran perumahan KIT dapat dilihat pada Tabel 13.

Biaya overhead terdiri dari biaya perijinan, biaya administrasi, dan biaya tak terduga sepeti bencana alam. Direncanakan sebanyak $8 \%$ dari total pendapatan per tahun.Biaya overhead dapat dilihat pada Tabel 14. 
Tabel 13.

Biaya Pemasaran Perumahan KIT (dalam Ribu Rupiah)

\begin{tabular}{|c|c|c|c|}
\hline \multirow{2}{*}{ Uraian } & \multicolumn{2}{|c|}{ Biaya Pemasaran } & \multirow{2}{*}{ Total } \\
\cline { 2 - 3 } & Personil & Event/Pameran & \\
\hline $\mathbf{2 0 1 6}$ & 15.000 .000 & & 15.000 .000 \\
\hline $\mathbf{2 0 1 7}$ & 16.650 .000 & 5.000 .000 & 21.650 .000 \\
\hline $\mathbf{2 0 1 8}$ & 18.481 .500 & & 18.481 .500 \\
\hline $\mathbf{2 0 1 9}$ & 20.514 .465 & & 20.514 .465 \\
\hline $\mathbf{2 0 2 0}$ & 22.771 .056 & 5.000 .000 & 27.771 .056 \\
\hline $\mathbf{2 0 2 1}$ & 25.275 .872 & & 25.275 .872 \\
\hline $\mathbf{2 0 2 2}$ & 28.056 .218 & & 28.056 .218 \\
\hline $\mathbf{2 0 2 3}$ & 31.142 .402 & & 31.142 .402 \\
\hline $\mathbf{2 0 2 4}$ & 34.568 .067 & & 34.568 .067 \\
\hline
\end{tabular}

Tabel 14.

Biaya Overhead Perumahan KIT (dalam Ribu Rupiah)

\begin{tabular}{|l|c|c|c|}
\hline & \multicolumn{3}{|c|}{ Biaya Overhead } \\
\hline $\mathbf{2 0 1 6}$ & - & $\mathbf{2 0 2 1}$ & 3.279 .792 \\
\hline $\mathbf{2 0 1 7}$ & 5.377 .053 & $\mathbf{2 0 2 2}$ & 2.732 .783 \\
\hline $\mathbf{2 0 1 8}$ & 6.050 .550 & $\mathbf{2 0 2 3}$ & 2.114 .639 \\
\hline $\mathbf{2 0 1 9}$ & 5.680 .096 & $\mathbf{2 0 2 4}$ & 2.093 .493 \\
\hline $\mathbf{2 0 2 0}$ & 5.366 .932 & \multicolumn{2}{|c|}{} \\
\hline
\end{tabular}

Rekapitulasi biaya pengembangan per tahun perumahan terdapat pada Tabel 15. Direncanakan keuntungan pengembang sebanyak $13 \%$ dari total pendapatan per tahun yang ditunjukkan pada Tabel 16.

Tabel 15.

Rekapitulasi Biaya Pengembangan Perumahan KIT (dalam Ribu Rupiah)

\begin{tabular}{|l|c|c|c|c|c|c|c|c|c|}
\hline \multicolumn{1}{|c|}{ Uraian } & $\mathbf{2 0 1 6}$ & $\mathbf{2 0 1 7}$ & $\mathbf{2 0 1 8}$ & $\mathbf{2 0 1 9}$ & $\mathbf{2 0 2 0}$ & $\mathbf{2 0 2 1}$ & $\mathbf{2 0 2 2}$ & $\mathbf{2 0 2 3}$ & $\mathbf{2 0 2 4}$ \\
\hline Biaya Konstruksi & & & & & & & & & \\
\hline Tipe 80/250 & 16.792 .832 & 18.472 .115 & & & & & & & \\
\hline Tipe 60/220 & & 8.116 .073 & 14.687 .474 & & & & & & \\
\hline Tipe 52/180 & & & 3.344 .481 & 18.111 .652 & 19.611 .523 & 16.436 .324 & 7.156 .649 & & \\
\hline Tipe 42/114 & & & & & & & 9.598 .119 & 9.049 .655 & 9.954 .621 \\
\hline Jalan \& Saluran & 20.796 .573 & & & & & & & & \\
\hline Masjid & 952 & 1.047 & & & & & & & \\
\hline Asrama & 14.616 & & & & & & & & \\
\hline Gedung TK & 3.129 & 3.442 & & & & & & & \\
\hline Gedung SD & 14.898 & & & & & & & & \\
\hline Biaya Cut \& Fill & 4.055 .100 & & & & & & & & \\
\hline Biaya Perizinan & 8.608 & & & & & & & & \\
\hline Biaya Pemasaran & 15.000 & 21.650 & 18.482 & 20.514 & 27.771 & 25.276 & 28.056 & 31.142 & 34.568 \\
\hline Biaya Overhead & - & 5.377 .053 & 6.050 .550 & 5.680 .096 & 5.366 .932 & 3.279 .792 & 2.732 .783 & 2.114 .639 & 2.093 .493 \\
\hline $\begin{array}{l}\text { Total Biaya } \\
\text { Pengembangan }\end{array}$ & 41.701 .708 & 31.991 .380 & 24.100 .987 & 23.812 .262 & 25.006 .226 & 19.741 .391 & 19.515 .608 & 11.195 .437 & 12.082 .681 \\
\hline
\end{tabular}

Tabel 16

Keuntungan Pengembang Perumahan KIT (dalam Ribu Rupiah)

\begin{tabular}{|l|c|c|c|}
\hline & \multicolumn{3}{|c|}{ Keuntungan Pengembang } \\
\hline $\mathbf{2 0 1 6}$ & - & $\mathbf{2 0 2 1}$ & 5.329 .661 \\
\hline $\mathbf{2 0 1 7}$ & 8.737 .712 & $\mathbf{2 0 2 2}$ & 4.440 .773 \\
\hline $\mathbf{2 0 1 8}$ & 9.832 .145 & $\mathbf{2 0 2 3}$ & 3.436 .289 \\
\hline $\mathbf{2 0 1 9}$ & 9.230 .155 & $\mathbf{2 0 2 4}$ & 3.401 .926 \\
\hline $\mathbf{2 0 2 0}$ & 8.721 .264 & \multicolumn{2}{|c|}{} \\
\hline
\end{tabular}

\section{F. Indikasi Nilai Pasar Tanah}

Indikasi nilai pasar tanah dihitung melalui arus kas dengan discount factor yang didapat menggunakan rumus (1). Perhitungan nilai pasar tanah dilakukan dalam jangka waktu 9 tahun, yaitu saat awal mulai konstruksi sampai selesai. Nilai pasar tanah nantinya didapat dengan cara mengurangi pendapatan dengan total biaya pengembangan dan keuntungan pengembang. Tabel arus kas indikasi nilai pasar tanah perumahan KIT terdapat pada Tabel 17. Nilai pasar mentah
Perumahan KIT diperoleh sebesar Rp. 57.914.000.000, dengan nilai sebesar Rp. 299.917 per $\mathrm{m}^{2}$.

Tabel 17.

Perhitungan Arus Kas Indikasi Nilai Pasar Tanah Perumahan KIT (dalam Ribu Rupiah)

\begin{tabular}{|c|c|c|c|c|c|c|c|c|c|}
\hline Uraian & 2016 & 2017 & 2018 & 2019 & 2020 & 2021 & 2022 & 2023 & 2024 \\
\hline Total Pendapatan & & 67.213 .168 & 75.631 .881 & 71.001.194 & 67.086 .646 & \begin{tabular}{|l|l|}
40.997 .395 \\
\end{tabular} & 34.159 .790 & 26.432 .989 & 26.168 .659 \\
\hline \begin{tabular}{|l|} 
Total Biaya \\
Pengembangan
\end{tabular} & 85.764 .854 & 36.475 .753 & 24.100.987 & 23.812.262 & 25.006 .226 & 19.741.391 & 19.515 .608 & 11.195 .437 & 12.082 .681 \\
\hline \begin{tabular}{|l|} 
Keuntungan \\
Pengembang
\end{tabular} & & 8.737 .712 & 9.832.145 & 9.230 .155 & 8.721 .264 & 5.329 .661 & 4.440 .773 & 3.436 .289 & 3.401 .926 \\
\hline $\begin{array}{l}\begin{array}{l}\text { Penerimaan Sisa } \\
(\text { Residual Value })\end{array} \\
\end{array}$ & $(85.764 .854)$ & 21.999 .703 & 41.698 .750 & 37.958 .777 & 33.359 .156 & 15.926 .342 & 10.203 .410 & 11.801 .264 & 10.684 .052 \\
\hline Discount Fa & \begin{tabular}{|l|}
0,939 \\
\end{tabular} & 0,882 & 0,828 & \begin{tabular}{|l|l|} 
& 0,777 \\
\end{tabular} & 0,7 & 0,6 & 0,6 & 0,604 & 0,567 \\
\hline Present Val & $(80.530 .380)$ & 19.396.242 & 34.520 .272 & 29.506 .234 & 24.348 .209 & 10.914 .866 & 6.565.957 & 7.130 .692 & 6.061 .631 \\
\hline Net Present V & & & & & 57.913 .723 & & & & \\
\hline $\begin{array}{l}\text { Nilai Pasar Tanah } \\
\text { Mentah }\end{array}$ & & & & & & & & & \\
\hline
\end{tabular}

\section{KESIMPULAN DAN SARAN}

Berdasarkan keseluruhan hasil analisis yang telah dilakukan dapat diperoleh hasil indikasi nilai pasar tanah di Kawasan Industri Tuban dengan metode Pengembangan Lahan sebesar Rp 299.917 per $\mathrm{m}^{2}$.

Saran yang dapat diberikan berdasarkan hasil analisis dalam Penelitian ini meliputi :

1) Biaya-biaya yang dibutuhkan untuk pengembangan diestimasi berdasarkan prosentase, akan lebih baik apabila biaya-biaya tersebut diestimasi sesuai kondisi yang sebenarnya.

2) Perlu ditinjau lagi biaya pengembangan yang diperlukan dalam pembanguna perumahan.

\section{DAFTAR PUSTAKA}

[1] Supardi. U., Basuki R.H., dan Mukminin. L.A., 2010, Tinjauan Konsep Prosedur, Teknik, Penilaian dan Properti. Jakarta: Mitra Wacana Media.

[2] Prawoto, Agus. 2015. Teori \& Praktek Penilaian Properti Edisi Ketiga. Yogyakarta: BPFE Universitas Gadjah Mada.

[3] Republik Indonesia. 2012. Peraturan Daerah Kabupaten Tuban No. 09 Tahun 12 tentang Rencana Tata Ruang Wilayah Kabupaten Tuban Tahun 2012-2032. Badan Perencanaan Pembangunan Daerah Kabupaten Tuban. Tuban.

[4] Hidayati, Wahyu dan Budi, Harjanto. 2003. Konsep Dasar Penilaian Properti. Yogyakarta: BPFE Universitas Gadjah Mada.

[5] Juwana, Jimmy S, 2005. Panduan Sistem Bangunan Tinggi : Untuk Arsitek Dan Praktis Bangunan. Jakarta: Erlangga.

[6] Republik Indonesia. 2007. Peraturan Menteri Pekerjaan Umum No.45/PRT/M/2007 tentang Pedoman Teknis Pembangunan Bangunan Gedung Negara. Menteri Pekerjaan Umum Republik Indonesia. Jakarta. 